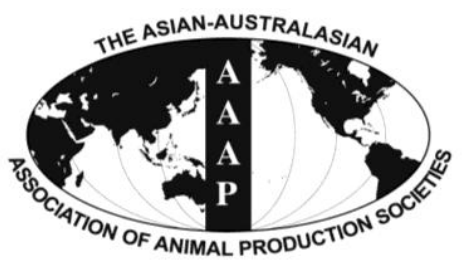

Asian-Aust. J. Anim. Sci.

Vol. 25, No. $9: 1229$ - 1236

September 2012

www.ajas.info

http://dx.doi.org/10.5713/ajas.2012.12189

\title{
Effects of Kisspeptin-10 on Lipid Metabolism in Cultured Chicken Hepatocytes
}

\author{
J. Wu, W. Fu, Y. Huang and Y. Ni* \\ Key Laboratory of Animal Physiology \& Biochemistry, Nanjing Agricultural University, Nanjing 210095, China
}

\begin{abstract}
Our previous studies showed that kisspeptin-10 (Kp-10) injected in vivo can markedly increase lipid anabolism in liver of quails. In order to investigate the direct effect of $\mathrm{Kp}-10$ on lipid metabolism of hepatocytes in birds, cells were separated from embryos livers and cultured in vitro with 0,100 and 1,000 nM Kp-10, respectively. The results showed that after $24 \mathrm{~h}$ treatment, cells viability was not affected by $100 \mathrm{nM} \mathrm{Kp}-10$, but showed a mild decrease with 1,000 nM Kp-10 compared to the control cells. Based on the results of the cell viability, $100 \mathrm{nM}$ dosage of $\mathrm{Kp}-10$ was selected for the further study and analysis. Compared with control cells, total cholesterol (Tch) contents in $100 \mathrm{nM}$ treated cells were increased by $51.23 \%$, but did not reach statistical significance, while the level of triglyceride (TG), high density of lipoprotein-cholesterol (HDL-C) and low density of lipoprotein-cholesterol (LDL-C) were significantly increased. Real-time PCR results showed that ApoVLDL-II mRNA expression had a tendency to increase, genes including sterol regulatory element-binding protein-1 (SREBP-1), acetyl coenzyme A carboxylase $\alpha$ (ACC $\alpha$ ), carnitine palmitoyltransferase 1 (CPT1), 3-hydroxyl-3-methylglutaryl-coenzyme A reductases (HMGCR) and stearyl coenzyme A dehydrogenase-1 (SCD1) mRNA in hepatocytes were significantly down-regulated by $100 \mathrm{nM} \mathrm{Kp}-10$. However, contrary to its gene expression, SREBP-1 protein expression was significantly up-regulated by $100 \mathrm{nM} \mathrm{Kp}-10$. Some of the significant correlations in mRNA expression were found between genes encoding hepatic factors or enzymes involved in lipid metabolism in liver of birds. These results indicate that Kp-10 stimulates lipid synthesis directly in primary cultured hepatocytes of chickens. (Key Words: Kisspeptin-10, Lipid Metabolism, Hepatocytes, Chicken)
\end{abstract}

\section{INTRODUCTION}

Kisspeptin-10, -14, and -13 are the split products of kisspeptin-54 encoded by kiss-1 gene, which are the endogenous ligands of $\mathrm{G}$ protein-coupled receptor-54 (GPR54) (Kotani et al., 2001). With a motif of argininephenylalanine-NH2 (RF-NH2) at the carboxyl terminus, each peptide can activate GPR54 with equal biopotency (Kotani et al., 2001; Oakley et al., 2009). Both the amino acids sequence and the function of kisspeptin-10 (Kp-10) are highly conserved among different species, including human, rodents and fish (van Aerle et al., 2008). In recent years, the effects of kisspeptins on reproductive function have been provoking an increasing interest. Kisspeptin/ GPR54 signal system has been documented as a pivotal signal pathway to regulate gonadotrophin-releasing hormone $(\mathrm{GnRH})$ secreting from the hypothalamus and then to control the onset of puberty (Seminara et al., 2003).

\footnotetext{
* Corresponding Author: Y. D. Ni. Tel: +86-2584399020, Fax: +86-2584398669, E-mail: niyingdong@njau.edu.cn Submitted Apr. 11, 2012; Accepted Jun. 13, 2012; Revised Jul. 16, 2012
}

Mutations in either the kiss-1 gene or the gene for its cognate receptor render the animal unable to reach puberty (de Roux, 2003; Funes, 2003; d'Anglemont de Tassigny et al., 2007). In contrast, injection of kisspeptin causes the sexual precocity, and kisspeptins are likely the most potent elicitors of $\mathrm{GnRH} /$ gonadotropin secretion known so far (Roa et al., 2009).

As in mammals, the avian reproduction is controlled by the axis of hypothalamus-pituitary gonad (HPG) and the secretion of GnRH from the hypothalamus is the key event to initiate the reproduction (Wingfield, 2005). Kisspeptin under low doses was sufficient to significantly increase plasma LH levels in the drake and the white-crowned sparrows by central administration (Saldanha et al., 2010; Charlier et al., 2011). Our previous studies also showed that Kp-10 stimulated progesterone secretion in cultured hens' granulosa cells (Xiao et al., 2010). These observations suggest the function of kisspeptins in regulating reproduction in vertebrates is highly conserved. Moreover, chronic repeated injections of $\mathrm{Kp}-10$ in vivo during juvenile can greatly promote the tempo of egg production in quail, 
which paralleled a marked increase in serum estrogen $\left(E_{2}\right)$ and lipid synthesis in liver (data not published). Unfortunately, till now, the mechanism underlying the increase of lipid synthesis in liver by Kp-10 is still a mystery.

In birds, each egg yolk contains extensive lipids (Moran, 2007), which includes about four gram of triglyceride (TG) (Bujo et al., 1997). Egg production is an energy-intensive process, requiring a large increase in lipid synthesis to support the demands of new yolk formation. Birds have the ability to store large quantities of excess energy (in the form of TG) in liver and in yolk of developing oocytes (Hermier, 1997). It is well known that liver is the primary site of lipogenesis in birds (Hermier, 1997), and it is generally accepted that hepatic lipogenesis and the export of lipids are crucial steps linked to oocyte growth and maturation (i.e., yolk formation). It has been well documented that estrogen stimulates hepatic lipid synthesis in birds (Lee et al., 2010). Thus, it's speculated that the effects of Kp-10 on stimulating lipid synthesis in liver of quails might be mediated by the increase of circulating estrogen and/or be the direct regulation in liver. The aim of the present study was to investigate a direct effect of $\mathrm{Kp}-10$ on stimulating lipid synthesis in hepatocytes of chickens cultured in vitro.

\section{MATERIAL AND METHODS}

\section{Materials}

Kisspeptin-10 (Cat. No. 2570) was purchased from Tocris Bioscience, USA. Medium 199 (M199) and penicillin-streptomycin were products of Gibco Company (Invitrogen Corporation, Shanghai, China). Fetal bovine serum (FBS), ITS (5 U/ml insulin, $5 \mu \mathrm{g} / \mathrm{ml}$ transferrin, 5 $\mathrm{ng} / \mathrm{ml}$ sodium selenite), dimethylsulfoxide (DMSO), Percoll and collagenase-II were bought from Sigma Chemical. 3(4,5-Dimethylthiazol-2-yl)-2,5-diphenyl-tetrazolium bromide (MTT) was purchased from Nanjing Shengxing Biotech (Nanjing, China). The contents of TG, Tch, HDLC and LDLC were measured by the commercial kits purchased from Beijing Applygen Company (Beijing, China).

\section{Primary culture of chicken hepatocytes}

Chicken embryonic hepatocytes were isolated and cultured following the method previously reported by Smedsrod (Smedsrod and Pertoft, 1985). In brief, hepatocytes were prepared from freshly dissected liver tissue of 13-d-old Hailan chick embryo. Liver was collected and washed with phosphate buffered saline (PBS) containing penicillin-streptomycin buffer for three times. During this process, gallbladder, sarcolemma and connective tissue were carefully removed. After that, liver was spliced into pieces (about $1 \mathrm{~mm}^{3}$ ). Collagenase-II was added to $1 \mathrm{mg} / \mathrm{ml}$ concentration and incubated in solution for digestion at $37^{\circ} \mathrm{C}$ for $20 \mathrm{~min}$, and then cell suspensions were collected. Density gradient centrifugation was used to separate the hepatocytes from other cells, which was conducted in a layer with $60 \%$ Percoll (Sigma, St. Louis, MO, USA). The cell suspension was layered on the Percoll layer and centrifuged for $8 \mathrm{~min}$ at 5,000 g. Hepatocytes were harvested from the $60 \%$ Percoll/PBS interface, washed three times with PBS, and re-suspended in M199 medium. The cells were counted and the viability was ascertained by trypan blue exclusion method. After two times washing, cells were incubated in a humidified incubator (Thermo incubator, Forma, USA) at $37^{\circ} \mathrm{C}$ with $5 \% \mathrm{CO}_{2}$ for $24 \mathrm{~h}$. The cells were then transferred to serum-free medium 199 supplemented with $1 \%$ (v/v) insulin-transferrin-Se (ITS) solution and penicillin-streptomycin for $24 \mathrm{~h}$. Cells were treated with Kp-10 or with PBS buffer as control for $24 \mathrm{~h}$.

The experiment was undertaken following the guidelines of Nanjing Agricultural University (Nanjing, China) Animal Ethics Committee.

\section{Cell viability assay}

Cell viability was measured by quantitative colorimetric assay with MTT method. MTT was dissolved in PBS at 5 $\mathrm{mg} / \mathrm{ml}$. Briefly, $20 \mu \mathrm{l}$ of MTT solution was added into each well, incubated at $37^{\circ} \mathrm{C}$ for $3 \mathrm{~h}$. After incubation, the medium with MTT was discarded, and $160 \mu \mathrm{l}$ of DMSO were added to dissolve the formed crystals and absorbance was measured at $450 \mathrm{~nm}$ with a microplate reader (Synergy, BioTek, USA). The cell viability was directly calculated by absorbance value.

\section{Gene expression analysis}

Total RNA was extracted from collected cells using TRIZOL reagent (Invitrogen Corporation, Shanghai, USA). The RNA concentration and quality was then quantified by measuring the absorbance at $260 \mathrm{~nm}$ by a photometer (Eppendorf, Germany). Ratios of absorption (260/280 nm) of all samples were between 1.8 and 2.0. Aliquots of RNA samples were subjected to electrophoresis with $1.4 \%$ agarose-formaldehyde gels stained with ethidium bromide to verify the integrity. Total RNA $(2 \mu \mathrm{g})$ were used for reverse transcription in a final volume of $25 \mu \mathrm{l}$ containing $1 \times$ RT-buffer, $100 \mathrm{U}$ Moloney Murine Leukemia Virus reverse transcriptase (M-MLV) (Promega, USA), $8 \mathrm{U}$ RNase inhibitor (Promega, USA), $5.3 \mu \mathrm{M}$ random hexamer primers and $0.8 \mathrm{mM}$ dNTP (TaKaRa, Japan), incubated at $37^{\circ} \mathrm{C}$ for $1 \mathrm{~h}$. RT reaction was terminated by heating at $95^{\circ} \mathrm{C}$ for $5 \mathrm{~min}$ and quickly cooling on ice.

Real-time PCR was performed in Mx3500P (Stratagene, USA). Mock RT and no template controls (NTC) were set to monitor the possible contamination of genomic DNA 
both at RT and PCR. The standard curves for each target gene, and melting curves were performed to insure a single specific PCR product for each gene. The volume of $25 \mu \mathrm{l}$ for PCR contains $2 \mu$ l of 16-fold dilution of RT product, 12.5 $\mu$ S SYBR Green Real-time PCR Master Mix (TOYOBO Ltd., Japan) and 0.6 to $1.0 \mu \mathrm{M}$ of each forward and reverse primers for target genes and internal standard gene (the information of primers was shown in Table 1). Chicken $\beta$-actin mRNA was used as a reference gene for normalization purpose. After initial denaturation at $95^{\circ} \mathrm{C}$ for $1 \mathrm{~min}$, the following PCR process was a three-step amplification program $\left(20 \mathrm{~s}\right.$ at $95^{\circ} \mathrm{C}, 20$ to $30 \mathrm{~s}$ at 60 to $64^{\circ} \mathrm{C}, 20 \mathrm{~s}$ at $72^{\circ} \mathrm{C}$ ) repeated 45 times. The PCR products for each gene were sent to Haojia Biotech, Ltd., for sequencing to verify the specificity. The reported sequences exactly accorded with those published in GenBank. The method of $2^{-\Delta \Delta \mathrm{Ct}}$ was used to analyze the real-time RT-PCR data. All samples were included in the same run of RT-PCR and repeated in triplicates.

\section{Western blot analysis}

After treatment, the cells were harvested and rinsed with PBS and then lysed with $100 \mu \mathrm{l}$ RIPA buffer, and kept antigraded and standed alternately for $30 \mathrm{~min}$. RIPA buffer contained $50 \mathrm{mM}$ Tris base (pH 7.4), $150 \mathrm{mM} \mathrm{NaCl}, 1 \mathrm{mM}$ EDTA, $1 \%(\mathrm{v} / \mathrm{v})$ NP-40, 0.25\% (w/v) Na-deoxycholate, 1 $\mathrm{mM} \mathrm{NaF}$, and $1 \%(\mathrm{v} / \mathrm{v})$ Halt protease inhibitor cocktail (Pierce Chemical Co., Rockford, USA). Cell lysates were centrifuged at $12,000 \mathrm{~g}$ for $10 \mathrm{~min}$ and the supernatant was removed. The pellet was dissolved in lysed buffer and the protein concentration was determined by bicinchoninic acid (BCA) method with Protein Assay Kit (Pierce Chemical Corp., Rockford, USA). After denaturation at $100^{\circ} \mathrm{C}$ for 5 min, $40 \mu \mathrm{g}$ protein samples were loaded into a $12 \%$ polyacrylamide gel, and then transferred onto a polyvinylidene difluoride membrane (Millipore Corp.,

Table 1. Primer sequences of the target genes

\begin{tabular}{|c|c|c|c|}
\hline Target genes & GenBank number & PCR products $(\mathrm{bp})$ & Primer sequences \\
\hline \multirow[t]{2}{*}{$\beta$-Actin } & NM205518 & 300 & F: 5'-TGCGTGACATCAAGGAGAAG-3' \\
\hline & & & R: 5'-TGCCAGGGTACATTGTGGTA -3' \\
\hline \multirow[t]{2}{*}{ CPT-1 } & AY675193 & 137 & F: 5'-GGAGAACCCAAGTGAAAGTAATGAA-3' \\
\hline & & & R: 5'-TGGAAACGACATAAAGGCAGAA-3' \\
\hline \multirow[t]{2}{*}{ SREBP-1 } & AY029924 & 145 & F: 5'-CTACCGCTCATCCATCAACG-3' \\
\hline & & & R: 5'-CTGCTTCAGCTTCTGGTTGC-3' \\
\hline \multirow[t]{2}{*}{ FAS } & J04485 & 195 & F: 5'- TGAAGGACCTTATCGCATTGC -3' \\
\hline & & & R: 5'- GCATGGGAAGCATTTTGTTGT -3' \\
\hline \multirow[t]{2}{*}{$\mathrm{ACC} \alpha$} & NM-205505 & 127 & F: 5'-AGTCCTGATTGAGCATGGCA-3' \\
\hline & & & R: 5'-CTCCAGATGGCGGTAGATTC-3' \\
\hline \multirow[t]{2}{*}{ ME } & AF408407 & 101 & F: 5'-AGTGCCTACCTGTGATGTTG-3' \\
\hline & & & R: 5'-GGCTTGACCTCTGATTCTCT-3' \\
\hline \multirow[t]{2}{*}{ SCD1 } & NM204890 & 107 & F: 5'-AGTGGTGTTGCTGTGCTTCA-3' \\
\hline & & & R: 5'-CTAAGGTGTAGCGCAGGATG-3' \\
\hline \multirow[t]{2}{*}{ HMGCR } & AB109635 & 244 & F: 5'- CTGGGTTTGGTTCTTGTTCA -3' \\
\hline & & & R: 5'-ATTCGGTCTCTGCTTGTTCA -3' \\
\hline \multirow[t]{2}{*}{ CYP7A1 } & AB 109636 & 106 & F: 5'-CATTCTGTTGCCAGGTGATGTT-3' \\
\hline & & & R: 5'-GCTCTCTCTGTTTCCCGCTTT-3' \\
\hline \multirow[t]{2}{*}{ SREBP-2 } & XM416222 & 108 & F: 5'-CCCAGAACAGCAAGCAAGG-3' \\
\hline & & & R: 5'-GCGAGGACAGGAAAGAGAGTG-3' \\
\hline \multirow[t]{2}{*}{ FABP2 } & AF380999 & 202 & F: 5'-GAGCTCCAGTCCCATGAAAA-3' \\
\hline & & & R: 5'-TCAGCAGCTCCATCTCACAC-3' \\
\hline \multirow[t]{2}{*}{ ApoA1 } & M17961 & 162 & F: 5'-ATGCCATCGCCCAGTTCG-3' \\
\hline & & & R: 5'-GAGCCTCGGTGTCCTTCA-3' \\
\hline \multirow[t]{2}{*}{ ApoB } & NM204323 & 87 & F: 5'-GCATCTCTGCATCTCAGGAAAGA-3' \\
\hline & & & R: 5'-GCAGGCTACAAACTAACAGATCCA-3' \\
\hline \multirow[t]{2}{*}{ VTG-II } & M1806 & 328 & F: 5'-GCACAAGTGAAGCTGGAGTGG-3' \\
\hline & & & R: 5'-AATTCTCGAGCACGGCAGAGG-3' \\
\hline \multirow[t]{2}{*}{$\mathrm{ICDH}$} & EST & 202 & F: 5'- ATGAAGAGGGGCTACGAGGT -3' \\
\hline & & & R: 5'- CCCATTCCATAACAGCCAAG -3' \\
\hline \multirow[t]{2}{*}{ ApoVLDL-II } & M25774 & 196 & F: 5'-ATGGTGCAATACAGGGCATT-3' \\
\hline & & & R: 5'-GGGAAACATCCAGCAAGAAC-3' \\
\hline
\end{tabular}




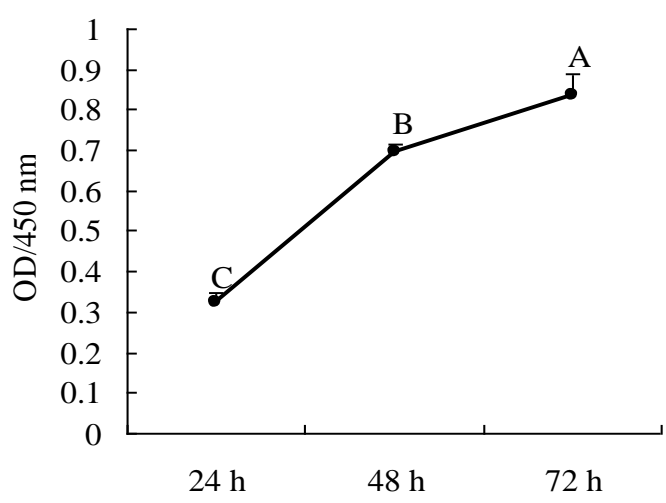

(A)

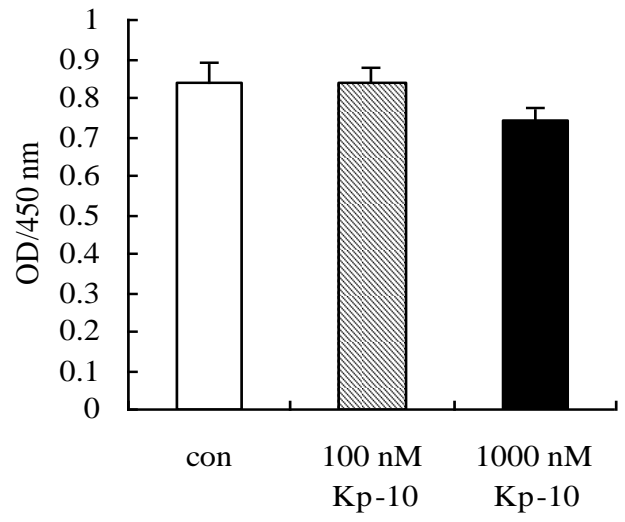

(B)

Figure 1. Effect of kisspeptin-10 on cell viability of chicken hepatocytes. (A) Cell viability of chicken hepatocytes cultured in vitro. (B) Effects of Kp-10 on the viability of chicken hepatocytes. Values are means \pm SEM. Mean values without same superscripts (A, B, C) are significantly different (one-way ANOVA) at the level of $\mathrm{p}<0.01$ by LSD tests, $\mathrm{n}=8$.

Fisher Scientific, IL, USA) at 100 voltage for $90 \mathrm{~min}$. Blocked with $3 \%(\mathrm{~m} / \mathrm{v})$ BSA for $2 \mathrm{~h}$, then the membranes were incubated with primary antibodies of SREBP-1 at 1:100 dilution (catalog No. ab3259, Abcam, Cambridge, UK) and $\beta$-actin at 1:5,000 dilution (catalog No. ab8227, Abcam, Cambridge, UK) at $4^{\circ} \mathrm{C}$ overnight. After washing, the membranes were incubated with horseradish peroxidase-conjugated anti-mouse $\mathrm{IgG}$ secondary antibody for $2 \mathrm{~h}$ at room temperature. The immunoblots were visualized by chemiluminescence detection (Pierce Chemical Corp., Rockford, USA) and quantified by integrated focal imaging system. The band densities of SRBBP-1 protein were normalized with that of $\beta$-actin.

\section{Statistical analysis}

The results were expressed as mean \pm SEM and differences were considered significant when $\mathrm{p}<0.05$ tested by ANOVA with SPSS 11.0 for windows (StatSoft, Inc. USA). Numbers used for statistics were noted in the figures and tables.

\section{RESULTS}

\section{Cell viability}

Cell viability was determined by MTT method. As shown in Figure 1A, cell viability was significantly increased on time-dependent from 24 to $72 \mathrm{~h}$ cultured in vitro $(\mathrm{p}<0.01)$. Figure $1 \mathrm{~B}$ showed that, compared with the control cells, 1,000 nM Kp-10 tended to decrease cell viability, while $100 \mathrm{nM} \mathrm{Kp}-10$ did not affect cell viability $(\mathrm{p}>0.05)$.

\section{Lipid metabolic parameters}

Table 2 showed that compared to the control cells, Tch content in $100 \mathrm{nM}$ treated hepatocytes was increased by $51.23 \%$, but did not reach the statistical significance
( $p>0.05$ ), while the level of TG, HDL-C and LDL-C was significantly increased $(p<0.05$ and $p<0.01$, respectively).

\section{Hepatic genes expression}

As shown in Figure 2, genes expression of SREBP-1, ACC $\alpha$, SCD1, CPT1 and HMGCR in $100 \mathrm{nM} \mathrm{Kp-10}$ treated cells were significantly down-regulated $(\mathrm{p}<0.05)$, FAS and ApoA1 genes expression tended to decrease ( $\mathrm{p}=$ 0.08 and 0.07 , respectively), while ApoVLDL-II mRNA transcription tended to increase $(p=0.07)$ compared with the control cells. There were no significant difference in SREBP-2, ME, ICDH, ApoB and FABP2 mRNA expression between Kp-10 treated and control cells $(\mathrm{p}>0.05)$.

\section{Correlations analysis among genes expression}

As shown in Table 3, some significant correlations were observed between gene encoding hepatic factors or enzymes linked with lipid metabolic process. Genes expression between SREBP-1 and FAS $(r=0.628, \mathrm{p}=$ $0.032)$, between SREBP-1 and SCD1 $(r=0.837, p=0.001)$, between ME and SCD1 $(\mathrm{r}=-0.643, \mathrm{p}=0.024)$, between FAS and SCD1 $(r=0.765, p=0.004)$, as well as between ACC $\alpha$ and SCD1 $(r=0.662, p=0.019)$ were significantly correlated $(\mathrm{p}<0.05)$. There was a mild correlation between

Table 2. Effect of Kp-10 on the concentrations of Tch, TG, HDL$\mathrm{C}$ and LDL-C in chicken hepatocytes

\begin{tabular}{lcl}
\hline & Con & $100 \mathrm{nM} \mathrm{Kp}-10$ \\
\hline Tch $(\mu \mathrm{g} / \mathrm{mg}$ protein $)$ & $156.69 \pm 27.46^{\mathrm{a}}$ & $236.96 \pm 62.79^{\mathrm{a}}$ \\
TG $(\mu \mathrm{g} / \mathrm{mg}$ protein $)$ & $253.57 \pm 63.38^{\mathrm{b}}$ & $515.15 \pm 142.35^{\mathrm{a}}$ \\
HDL-C (nmol/mg protein) & $193.15 \pm 37.08^{\mathrm{b}}$ & $445.54 \pm 141.11^{\mathrm{a}}$ \\
LDL-C (nmol/mg protein) & $73.85 \pm 17.60^{\mathrm{b}}$ & $403.11 \pm 154.98^{\mathrm{a}}$ \\
\hline
\end{tabular}

Values are means \pm SEM. Mean values without common superscript $(a, b)$ differ significantly between the control (Con) and Kp-10 treated group $(\mathrm{p}<0.05, \mathrm{n}=8)$. Tch $=$ Total cholesterol; $\mathrm{TG}=$ Triglyceride; $\mathrm{HDLC}=$ High density lipoprotein-cholesterol; LDLC = Low density lipoproteincholesterol. 


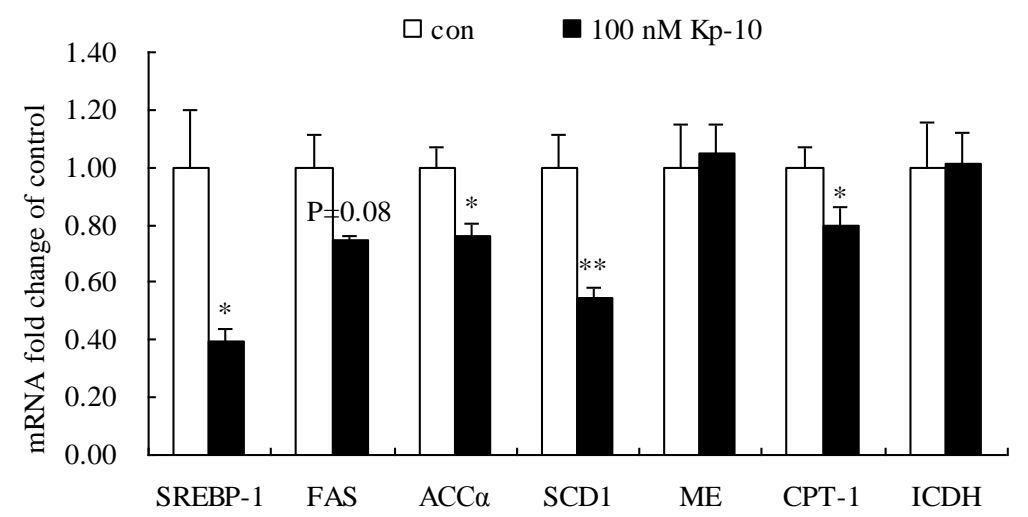

(A)

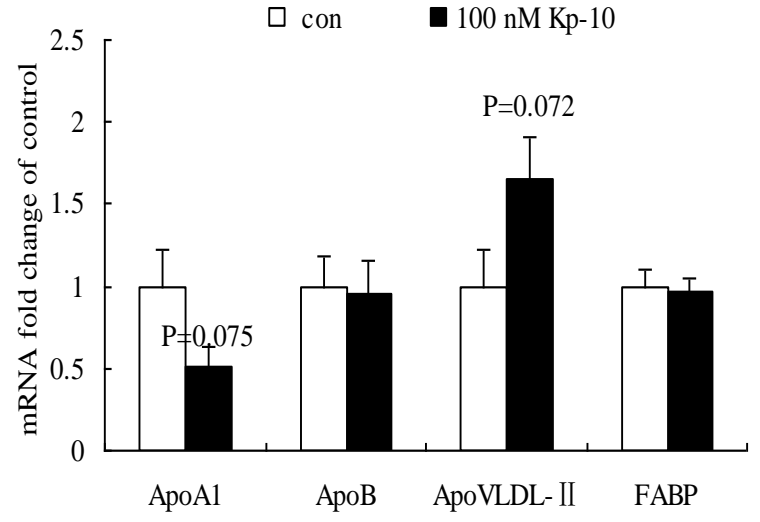

(B)

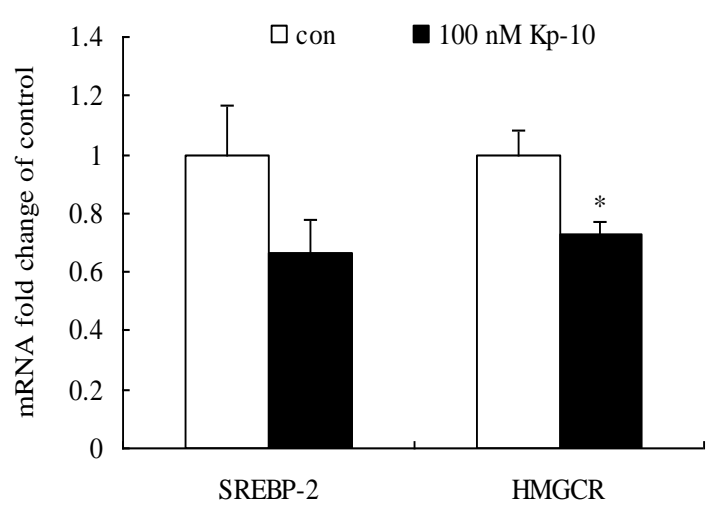

(C)

Figure 2. Changes of gene expression in chicken hepatocytes by kisspeptin-10. (A) Effects of Kp-10 on the expression of lipogenic genes in chicken hepatocytes cultured in vitro. (B) Effects of Kp-10 on the expression of lipids transporting genes in chicken hepatocytes cultured in vitro. (C) Effects of Kp-10 on the expression of cholesterol metabolic genes in chicken hepatocytes cultured in vitro. Values are means \pm SEM. The data with one and two asterisk are significantly different (one-way ANOVA) at the level of $\mathrm{p}<0.05$ and 0.01 , respectively, by LSD tests, compared with control, $\mathrm{n}=8$.

Table 3. Correlations between genes expression related to lipid metabolism in chicken hepatocytes cultured in vitro

\begin{tabular}{|c|c|c|c|c|c|c|c|c|}
\hline & FAS & CPT1 & $\mathrm{ACC} \alpha$ & SCD1 & $\mathrm{ME}$ & SREBP-1 & SREBP-2 & HMGCR \\
\hline & & & & & & & & \\
\hline FAS & 1.000 & $\begin{array}{c}0.334 \\
(0.289)\end{array}$ & $\begin{array}{c}0.457 \\
(0.135)\end{array}$ & $\begin{array}{c}0.765 \\
(0.004)\end{array}$ & $\begin{array}{l}-0.325 \\
(0.303)\end{array}$ & $\begin{array}{c}0.618 \\
(0.032)\end{array}$ & $\begin{array}{c}0.295 \\
(0.353)\end{array}$ & $\begin{array}{c}0.685 \\
(0.014)\end{array}$ \\
\hline CPT-1 & & 1.000 & $\begin{array}{c}0.075 \\
(0.816)\end{array}$ & $\begin{array}{c}0.161 \\
(0.617)\end{array}$ & $\begin{array}{l}-0.179 \\
(0.579)\end{array}$ & $\begin{array}{c}0.016 \\
(0.961)\end{array}$ & $\begin{array}{l}-0.455 \\
(0.137)\end{array}$ & $\begin{array}{c}0.155 \\
(0.631)\end{array}$ \\
\hline ACC & & & 1.000 & $\begin{array}{c}0.662 \\
(0.019)\end{array}$ & $\begin{array}{l}-0.405 \\
(0.192)\end{array}$ & $\begin{array}{c}0.570 \\
(0.053)\end{array}$ & $\begin{array}{c}0.220 \\
(0.492)\end{array}$ & $\begin{array}{c}0.544 \\
(0.068)\end{array}$ \\
\hline SCD1 & & & & 1.000 & $\begin{array}{l}-0.643 \\
(0.024)\end{array}$ & $\begin{array}{c}0.837 \\
(0.001)\end{array}$ & $\begin{array}{c}0.095 \\
(0.770)\end{array}$ & $\begin{array}{c}0.915 \\
(0.000)\end{array}$ \\
\hline ME & & & & & 1.000 & $\begin{array}{l}-0.405 \\
(0.191)\end{array}$ & $\begin{array}{c}0.438 \\
(0.155)\end{array}$ & $\begin{array}{l}-0.676 \\
(0.016)\end{array}$ \\
\hline SREBP-1 & & & & & & 1.000 & $\begin{array}{c}0.276 \\
(0.386)\end{array}$ & $\begin{array}{c}0.821 \\
(0.001)\end{array}$ \\
\hline SREBP-2 & & & & & & & 1.000 & $\begin{array}{l}-0.057 \\
(0.860)\end{array}$ \\
\hline HMGCR & & & & & & & & 1.000 \\
\hline
\end{tabular}


SREBP-1 and ACC $\alpha$ mRNA expression ( $\mathrm{p}=0.053$ ). Positive correlation also existed between HMGCR and TG metabolism genes expressed in hepatocytes including SREBP-1, FAS, SCD1 and ME $(\mathrm{p}<0.05)$. However, no significant correlations were observed between gene expressions involved in lipid transporting $(\mathrm{p}>0.05)$.

\section{Hepatic SREBP-1 protein content}

As shown in Figure 3, hepatic SREBP-1 protein content was determined by western blot. In contrast to the abundance of mRNA expression, hepatic SREBP-1 protein content was significantly increased by $100 \mathrm{nM} \mathrm{Kp}-10$ treatment $(\mathrm{p}<0.05)$.

\section{DISCUSSION}

There have been numerous publications on the biological effects of kisspeptins on reproduction. However, the data about the effects of kisspeptins on lipid metabolism is really scarce. We reported herein the first time that Kp-10 can directly stimulate lipid synthesis in chicken hepatocytes cultured in vitro, which was associated with significant changes of genes and protein expression involved in lipogenesis.

The previous studies showed that Kp-10 i.p. repeated injections significantly promoted the tempo of egg laying in Japanese quail, which paralleled a significant increase of TG and Tch content in liver as well as in blood (data not published). In rodents, the expression of kiss-I gene might relate to the increase of body weight and change with the high fat diets (Moral et al., 2011; Quennell et al., 2011). Kisspeptin might directly reduce the hepatic lipid peroxidation, preventing the negative effect of lipid peroxidation on intracellular regulatory mechanisms managing the release of hypothalamic hormones leading to defective neurotransmission (Aydin et al., 2010). However, these observations suggested that there is a relationship between kisspeptin and lipid metabolism.

In birds, liver is the main site for lipogenesis (Hermier, 1997). The biological process of lipogenesis is regulated by sterol regulate element binding proteins (SREBPs) transcription factors family. Till now, three kinds of SREBPs were identified including SREBP-1a, SREBP-1c and SREBP-2. SREBP-1 gene is highly expressed in liver, and directly regulates the expression of enzymes involved in the lipogenesis process, such as FAS, ACC $\alpha$, SCD1 and ME (Gondret et al., 2001; Kersten, 2001; Shimano and Yahagi, 1999). SREBP-2 mainly regulates enzymes involved in the cholesterol metabolism, such as HMGCR. In the present study, TG, HDLC as well as LDLC contents in hepatocytes were markedly increased by Kp-10 treatment, whereas the gene expression of the key factor SREBP-1 and enzymes, such as ACC $\alpha$, FAS and SCD1 involved in lipogenic process, their mRNA expression were greatly decreased by Kp-10. On the contrary, the content of SREBP-1 protein in hepatocytes was significantly increased by $100 \mathrm{nM} \mathrm{Kp}-10$, which indicates the post-transcriptional regulation. In a good agreement with the present results, it is reported that enzyme involved in the lipid synthesis process were mainly experienced post-transcription regulation, especially in SREBP-1 transgenic mice (Shimomura et al., 1998).

Correlation analysis showed that significant positive correlations were observed among genes expression involved in lipid metabolism. SREBP-1 mRNA expression was general correlated with other genes involved in lipid metabolism. Moreover, there were obvious correlations among genes expression involved in cholesterol and triglyceride metabolism. Our results were consistent with previous report about the correlations among lipogenic genes expression in liver of chicken (Richards et al., 2003), suggesting that $\mathrm{Kp}-10$ regulated the relevant genes

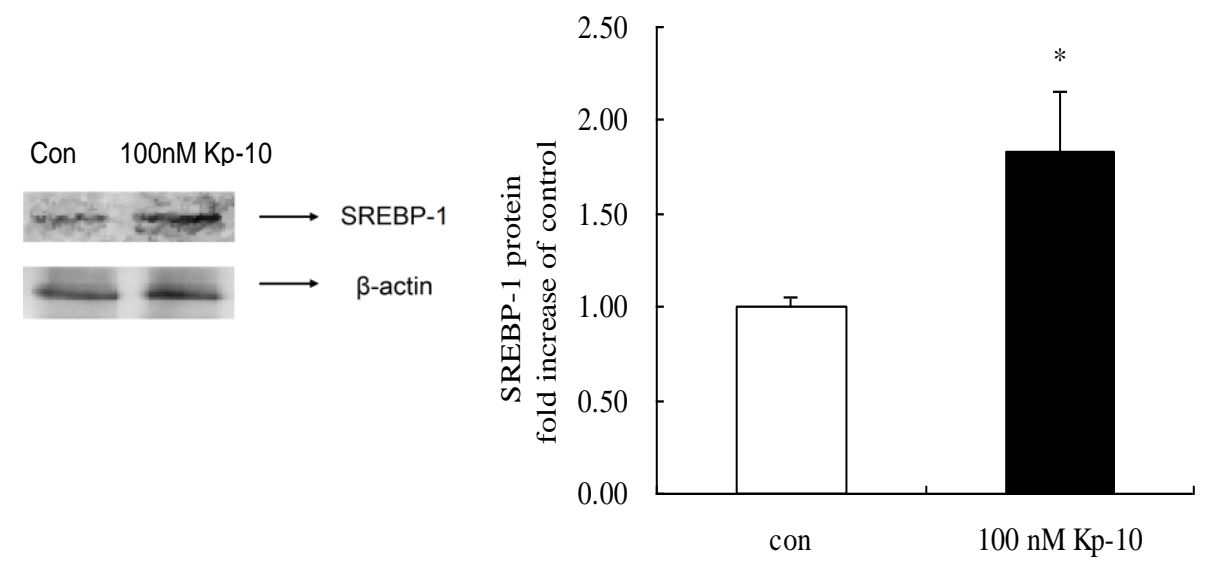

Figure 3. Effect of kisspeptin-10 on the expression of SREBP-1 protein in chicken hepatocytes cultured in vitro. Values are means \pm SEM. The data with asterisk is significantly different (one-way ANOVA) at the level of $\mathrm{p}<0.05$ by LSD tests, compared with control, $\mathrm{n}=8$. 
expression involved in lipid metabolism, but did not change the endogenous correlation in genes expression pattern.

We reported the direct effect of $\mathrm{Kp}-10$ on stimulating hepatic lipid metabolism in vitro cultured hepatocytes of chicken. However, because the specific receptor for kisspeptins has not been identified in avian species, the signal pathway of $\mathrm{Kp}-10$ to regulate lipid metabolism in hepatocytes is still unknown. Studies conducted in mammals showed the classical pathway of kisspeptin, when kisspeptin binding to GPR54, the phospholipase $\mathrm{C}$ can be activated to produce phosphatidylinositol 4,5-bisphosphate (PIP2), inositol triphosphate (IP3) and diacylglycerol (DAG) and to transmit the signal in cell (Kirby et al., 2010). The mechanism underlying the effects of $\mathrm{Kp}-10$ on lipid synthesis in hepatocytes of chicken still awaits further study.

\section{ACKNOWLEDGEMENTS}

This work was supported by National Nature Science Foundation of China (Project No. 30800809) and a Project Funded by the Priority Academic Program Development of Jiangsu Higher Education Institutions (PAPD) and Chinese National High-tech R\&D Program (863 Program, 2006AA10Z320).

\section{REFERENCES}

Aydin, M., S. Oktar, Z. Yonden, O. H. Ozturk and B. Yilmaz. 2010. Direct and indirect effects of kisspeptin on liver oxidant and antioxidant systems in young male rats. Cell Biochem. Funct. 28:293-299.

Bartel, D. P. 2009. MicroRNAs: target recognition and regulatory functions. Cell 136:215-233.

Bujo, H., M. Hermann, K. A. Lindstedt, J. Nimpf and W. J. Schneider. 1997. Low density lipoprotein receptor gene family members mediate yolk deposition. J. Nutr. 127:801-804.

Charlier, T. D., A. E. Newman, S. A. Heimovics, K. W. Po, C. J. Saldanha and K. K. Soma. 2011. Rapid effects of aggressive interactions on aromatase activity and oestradiol in discrete brain regions of wild male white-crowned sparrows. J. Neuroendocrin. 23:742-753.

d'Anglemont de Tassigny, X., L. A. Fagg, J. P. C. Dixon, K. Day, H. G. Leitch, A. G. Hendrick, D. Zahn, I. Franceschini, A. Caraty, M. B. Carlton, S. A. Aparicio and W. H. Colledge. 2007. Hypogonadotropic hypogonadism in mice lacking a functional kiss1 gene. Proc. Natl. Acad. Sci. USA. 104:1071410719.

de Roux, N. 2003. Hypogonadotropic hypogonadism due to loss of function of the kiss1-derived peptide receptor GPR54. Proc. Natl. Acad. Sci. USA. 100:10972-10976.

Funes, S. 2003. The Kiss-1 receptor GPR54 is essential for the development of the murine reproductive system. Biochem. Biophys. Res. Commun. 312:1357-1363.

Gondret, F., P. Ferre and I. Dugail. 2001. ADD-1/SREBP-1 is a major determinant of tissue differential lipogenic capacity in mammalian and avian species. J. Lipid Res. 42:106-113.
Henke, J. I., D. Goergen, J. Zheng, Y. Song, C. G. Schüttler, C. Fehr, C. Jünemann and M. Niepmann. 2008. MicroRNA-122 stimulates translation of hepatitis C virus RNA. EMBO. J. 27:3300-3310

Hermier, D. 1997. Lipoprotein metabolism and fattening in poultry. J. Nutr. 127:805-808.

Kersten, S. 2001. Mechanisms of nutritional and hormonal regulation of lipogenesis. EMBO. Rep. 2:282-286.

Kirby, H. R., J. J. Maguire, W. H. Colledge and A. P. Davenport. 2010. Kisspeptin receptor nomenclature, distribution, and function. Pharmacol. Rev. 62:565-578.

Kotani, M., M. Detheux, A. Vandenbogaerde, D. Communi, J. M. Vanderwinden, P. E. Le, S. Brézillon, R. Tyldesley, N. SuarezHuerta, F. Vandeput, C. Blanpain, S. N. Schiffmann, G. Vassart and M. Parmentier. 2001. The metastasis suppressor gene Kiss1 encodes kisspeptins, the natural ligands of the orphan $\mathrm{G}$ protein-coupled receptor GPR54. J. Biol. Chem. 276:3463134636.

Lee, B. K., J. S. Kim, H. J. Ahn, J. H. Hwang, J. M. Kim, H. T. Lee, B. K. An and C.W. Kang. 2010. Changes in hepatic lipid parameters and hepatic messenger ribonucleic acid expression following estradiol administration in laying hens (Gallus domesticus). Poult. Sci. 89:2660-2667.

Lee, D. K., T. Nguyen, G. P. O'Neill, R. Cheng, Y. Liu, A. D. Howard, N. Coulombe, C. P. Tan, A.T. Tang-Nguyen, S. R. George and B. F. O'Dowd. 1999. Discovery of a receptor related to the galanin receptors. FEBS Lett. 446:103-107.

Moral, R., R. Escrich, M. Solanas, E. Vela, I. Costa, M. C. Villa and E. Escrich. 2011. Diets high in corn oil or extra-virgin olive oil provided from weaning advance sexual maturation and differentially modify susceptibility to mammary carcinogenesis in female rats. Nutr. Cancer 63:410-420.

Moran, E. T. 2007. Nutrition of the developing embryo and hatchling. Poult. Sci. 86:1043-1049.

Oakley, A. E., D. K.Clifton and R. A. Steiner. 2009. Kisspeptin signaling in the brain. Endocr. Rev. 30:713-743.

Ohtaki, T., Y. Shintani, S. Honda, H. Matsumoto, A. Hori, K. Kanehashi, Y. Terao, S. Kumano, Y. Takatsu, Y. Masuda, Y. Ishibashi, T. Watanabe, M. Asada, T. Yamada, M. Suenaga, C. Kitada, S. Usuki, T. Kurokawa, H. Onda, O. Nishimura and M. Fujino. 2001. Metastasis suppressor gene Kiss-1 encodes peptide ligand of a G-protein-coupled receptor. Nature 411:613-617.

Orom, U. A., F. C. Nielsen and A. H. Lund. 2008. MicroRNA-10a binds the 5'UTR of ribosomal protein mRNAs and enhances their translation. Mol. Cell 30:460-471.

Quennell, J. H., C. S. Howell, J. Roa, R. A. Augustine, D. R. Grattan and G. M. Anderson. 2011. Leptin deficiency and dietinduced obesity reduce hypothalamic kisspeptin expression in mice. Endocrinology 152:1541-1550.

Richards, M. P., S. M. Poch, C. N. Coon, R. W. Rosebrough, C. M. Ashwell and J. P. McMurtry. 2003. Feed restriction significantly alters lipogenic gene expression in broiler breeder chickens. J. Nutr. 133:707-715.

Roa, J., J. M. Castellano, V. M. Navarro, D. J. Handelsman, L. Pinilla and M. Tena-Sempere. 2009. Kisspeptins and the control of gonadotropin secretion in male and female rodents. Peptides 30:57-66.

Saldanha, C. J., B. J. Walters and G. S. Fraley. 2010. Neurons that 
co-localize aromatase- and kisspeptin-like immunoreactivity may regulate the HPG axis of the Mallard drake (Anas platyrhynchos). Gen. Comp. Endocrinol. 166:606-613.

Seminara, S. B., S. Messager, E. E. Chatzidaki, R. R. Thresher, J. S. Jr. Acierno, J. K. Shagoury, Y. Bo-Abbas, W. Kuohung, K. M. Schwinof, A. G. Hendrick, D. Zahn, J. Dixon, U. B. Kaiser, S. A. Slaugenhaupt, J. F. Gusella, S. O'Rahilly, M. B. Carlton, W. F. Jr. Crowley, S. A. Aparicio and W. H. Colledge. 2003. The GPR54 gene as a regulator of puberty. N. Engl. J. Med. 349:1614-1627.

Shi, R. and V. L. Chiang. 2005. Facile means for quantifying microRNA expression by real-time PCR. Biotechniques 39:519-525.

Shimano, H., N. Yahagi, M. Amemiya-Kudo, A. H. Hasty, J. Osuga, Y. Tamura, F. Shionoiri, Y. Iizuka, K. Ohashi, K. Harada, T. Gotoda, S. Ishibashi and N. Yamada. Sterol regulatory element-binding protein-1 as a key transcription factor for nutritional induction of lipogenic enzyme genes. J. Biol. Chem. 274:35832-35839.
Shimomura, I., H. Shimano, B. S. Korn, Y. Bashmakov and J. D. Horton. 1998. Nuclear sterol regulatory element-binding proteins activate genes responsible for the entire program of unsaturated fatty acid biosynthesis in transgenic mouse liver. J. Biol. Chem. 273:35299-35306.

Smedsrod, B. and B. Pertoft. 1985. Preparation of pure hepatocytes and reticuloendothelial cells in high yield from a single rat liver by means of Percoll centrifugation and selective adherence. J. Leukoc. Biol. 38:213-230.

van Aerle, R., P. Kille, A. Lange and C. R. Tyler. 2008. Evidence for the existence of a functional Kiss1/Kiss1 receptor pathway in fish. Peptides 29:57-64.

Wingfield, J. C. 2005. Historical contributions of research on birds to behavioral neuroendocrinology. Horm. Behav. 48:395-402.

Xiao, Y. Q., Y. D. Ni, Y. B. Huang, J. Wu, R. Grossmann and R. Q. Zhao. 2011. Effects of kisspeptin-10 on progesterone secretion in cultured chicken ovarian granulosa cells from preovulatory (F1)-F(3) follicles. Peptides 32:2091-2097. 